\title{
Genetic Variability of Pre and Post-Fragmentation Cohorts of Aspidosperma polyneuron Muell. Arg. (Apocynaceae)
}

\author{
José Marcelo Domingues Torezan ${ }^{1}$, Rogério Fernandes de Souza ${ }^{2}$, Paulo Maurício Ruas ${ }^{2}$, \\ Claudete de Fátima Ruas ${ }^{2}$, Elvis Hassmann Camargo ${ }^{1}$ and André Luís Laforga Vanzela ${ }^{2 *}$ \\ ${ }^{I}$ Departamento de Biologia Animal e Vegetal; ${ }^{2}$ Departamento de Biologia Geral; CCB; Universidade Estadual de \\ Londrina; andrevanzela@uel.br; C.P. 6001; 86051-990; Londrina - PR - Brazil
}

\begin{abstract}
RAPD was used to access the genetic variability in Aspisdosperma polyneuron, a long-lived, late-reproducing tropical tree, and highly important for the Atlantic Forest. RAPD profiles from adults (pre-fragmentation, >300 years old) and seedlings (postfragmentation, <<50 years old) were analyzed. Results showed a decrease of genetic polymorphism of post-fragmentation cohorts in small fragments and higher genetic diversity within population. The genetic diversity distribution suggested the establishment of fragments as protected reserves, and the transference of seedlings among fragments for conservation of A. polyneuron.
\end{abstract}

Key words: Aspidosperma, DNA markers, forest fragmentation, genetic variability, Peroba-rosa, RAPD

\section{INTRODUCTION}

The Seasonal Semidecidual Forest of the North Paraná state (Southern Brazil), where only $2 \%$ of mature Atlantic forest are remaining, is one of the most threatened Brazil's ecosystems, represented by almost only small isolated fragments, many of which exhibiting structural alterations, due to selective logging, reduction of populations, and edge effects (Kapos, 1989; Malcolm, 1994). The remaining populations have to deal with isolation effects, reduced between-patch dispersion, lack of pollinators and dispersers. The overall effects of these processes are gene flow reduction and endogamy increase (Murcia, 1996).

According to Simberloff (1998), conservation strategies based on keystone species can contribute to the conservation of entire ecosystems. One of these strategies is the use of genetic diversity monitoring as a tool to access key species populations status, and use this information to propose methods for habitat fragments conservation and management. Aspidosperma polineuron Muell. Arg., locally named as Perobarosa, can be seen as a keystone species in Seasonal Semidecidual Forest, due to its high biomass (up to $40 \%$ of total aboveground live biomass, Trevisan, 1998). A. polyneuron was one of the most common tree species in Northern Paraná region and it was intensely used for buildings and furniture. Due to its late reproductive phase (50 years or more) and very slow growth rate (10 to 15 years to reach $5 \mathrm{~cm}$ of breast height diameter), A. polyneuron conservation cannot rely only in ex situ strategies, such as seed collections. Genetic variability conservation of this species can only be achieved through conservation of natural populations, which are strongly reduced and scattered due to heavy fragmentation of Atlantic Forest.

\footnotetext{
*Author for correspondence
} 
DNA-based molecular techniques have been used in many plant population genetic studies (Lerceteau et al., 1997; Gillies et al., 1999; Sales et al., 2001; Caraffa et al., 2002). According to Lu et al. (1996), intra and inter-population genetic diversity is better accessed when randomly dispersed molecular markers are detected, because they cover a higher genome portion. Molecular markers obtained by RAPD (Random Amplified Polymorphic DNA) show those characteristics and can be useful for biodiversity studies.

The purpose of this study was to screen the genetic variability of fragmented $A$. polyneuron populations, using RAPD markers, in order to help assess the actual level of forest fragments conservation of different sizes and isolation degrees. One key feature of this study was that, as a consequence of $A$. polyneuron life history traits (long life - up to hundreds of years, slow growth and late reproductive age), it was possible to identify a pre-fragmentation cohort (the today's adults) and a post-fragmentation one (the seedlings), as long as the process of fragmentation in our study area has 60-80 years only.

\section{MATERIAL AND METHODS}

Sampling sites were selected visiting different fragments to verify the occurrence of adults and seedlings of A. polyneuron, and using a forest map derived from Landsat-TM imagery. The process was finished with 6 fragments varying in size and isolation degrees. A conservation unit "Parque Estadual Mata dos Godoy" (PEMG) was included as the greater and the best conserved fragment, free of selective logging and other direct impacts. Data about size of fragments and border-to-border distance to the nearest neighbor (NND) containing populations of $A$. polyneuron were recorded. Distances between pairs of sample sites were recorded ignoring fragment borders.

\section{DNA extraction, amplification and gel electrophoresis}

Samples of young leaves of 10 adults were collected, and packed in ice chests for transport and stored at $-20^{\circ}$ C. Seedlings were removed from the field, transferred to the greenhouse and leaves where collected and stored at $-20^{\circ} \mathrm{C}$.

Genomic DNA extraction was carried out following $\mathrm{Yu}$ et al. (1993), with minor modifications. DNA concentration was estimated using a DyNA Quant-200 (Hoefer-Pharmacia), according to manufacturer's instructions. The PCR reactions were performed in a final volume of 15 $\mu$ l, containing 1.2 U Taq polimerase; $1.5 \mu \mathrm{l}$ of $10 \mathrm{X}$ enzyme buffer; $3.5 \mathrm{mM}$ of $\mathrm{MgCl}_{2} ; 0.4 \mathrm{mM}$ of each dATP, dTTP, dCTP, and dGTP; $0.4 \mu \mathrm{M}$ of 10 mer arbitrary primers, and $30 \mathrm{ng}$ of template DNA. Samples were amplified using a thermal cycler PTC 100 MJ Research, programmed with 3 min at $94^{\circ} \mathrm{C}$ for initial DNA denaturation, followed by 40 cycles of $15 \mathrm{sec}$ at $94^{\circ} \mathrm{C}, 45 \mathrm{sec}$ at $35^{\circ} \mathrm{C}$, and $2 \mathrm{sec}$ at $72^{\circ} \mathrm{C}$. The cycle finished at $72^{\circ} \mathrm{C}$ for $7 \mathrm{~min}$.

Fifteen out of 118-tested RAPD primers (Operon Technologies, series: OPN, OPR, OPAF, OPAE, OPAS, OPAD, OPAT and OPP) were selected, according to consistency, reproducibility and polymorphism degree of electrophoretic bands. Electrophoresis of amplified samples were made at $130 \mathrm{~V}$, in $1.0 \%$ Agarosis (Gibco), containing $3 \mu 1$ of $10 \mathrm{~g} / \mathrm{ml}$ ethidium bromide in TAE buffer $(0.04 \mathrm{M}$ Tris-acetato; 0,01M EDTA, pH 7. 5-7. 8).

\section{Statistical analysis}

Statistical analysis was performed using the TFPGA software (Miller, 1997) for calculations of polymorphic loci number $(P-95 \%$ criterion) and polymorphic loci percentage $(\% P)$, and genetic diversity index $(H)$ for each population, and interpopulation variance $\left(\Phi_{\mathrm{ST}}\right)$ and gene flow $[\mathrm{Nm}$ $\left.=\left(1-\Phi_{\mathrm{ST}}\right) / 4 \Phi_{\mathrm{ST}}\right]$ according to criterion of Lynch and Milligan (1994). A dendrogram was constructed based on a Jaccard similarity coefficient matrix, using the UPGMA method. The cophenetic correlation of these matrix was done using Mantel (1968) test. Popgene software (Yeh et al., 2000) was used for calculation of Shannon diversity index $(I)$, total genetic diversity $\left(H_{T}\right)$, and genetic diversity within populations $\left(H_{S}\right)$.

Tests were performed following three configurations: (i) all joined plants, (ii) adults plus seedlings from each fragment (the fragment as a sample unit), and (iii) all adults clustered compared to seedlings clusters of each fragment.

\section{RESULTS}

A total of 118 primers were tested, and fifteen of these were chosen for the DNA amplification. The number of bands scored by selected primers ranged from 3 (OPAT-14) to 14 (OPAT-15). Seventy-seven (78.6\%) out of 98 DNA markers 
were polymorphic, under $95 \%$ of polymorphism criterion. Genetic diversity indexes were calculated for both adults and seedlings separately, and the data was used to access the influence of the last 60 years old regional forest fragmentation process. The adults were considered as the control, because they were much older than 60 years, and the seedlings were considered as postfragmentation samples.

The total genetic diversity $\left(H_{T}=0.278 \pm 0.03\right)$ and within-population $(H s=0.195 \pm 0.02)$ was estimated for RAPD markers for all populations together. Genetic diversity indexes, as genetic diversity index of Nei $(H)$, Shannon index $(I)$, polymorphic loci number $(P)$, and polymorphic loci percent $(\% \mathrm{P})$, were calculated for each population, and it was higher for the three sites in the PEMG (Table 1). Average genetic diversity for the whole PEMG is $H=0.312$ (seedlings plus adults). Other sites have shown values ranging from $H=0.125$ (Fazenda São José) to $H=0.208$ (Patrimônio Regina). Results showed a higher genetic diversity in the pool of adults $(H=0.287)$ when compared with the seedlings of each fragment, except for the PEMG samples, which exhibited diversity close to that obtained for the adults (Table 1). Although the samples of largest area (PEMG) exhibited higher genetic diversity than some of the small areas, the coefficient of correlation between size of areas and genetic diversity was not significant.

The $\Phi_{S T}$ component, that served as differentiation index among the populations of different fragments (Table 2), was not significant for samples collected in the PEMG when comparing adults and seedlings together. However, all the $\Phi_{S T}$ values were higher than 0.05 , which indicated a higher level of genetic structuring of these populations. The estimated gene flow $(\mathrm{Nm})$ was higher to 1.0 only among PEMG samples, as well as between PEMG-1 and Patrimônio Regina (1.199, Table 2). The $\Phi_{\mathrm{ST}}$ values, both calculated with and without the adult individuals showed no significant correlation with the physical distance between fragments (Fig. 1).

Coefficients of variation for errors associated with estimated genetic distance among A. polyneuron genotypes were calculated for different numbers of RAPD markers and the results indicated that 50 bands would result in a coefficient near $10 \%$, being $6.43 \%$ the result for 98 markers. This indicated that further increase in the number of markers could not result in an important reduction in the coefficient of variation (Fig. 2).

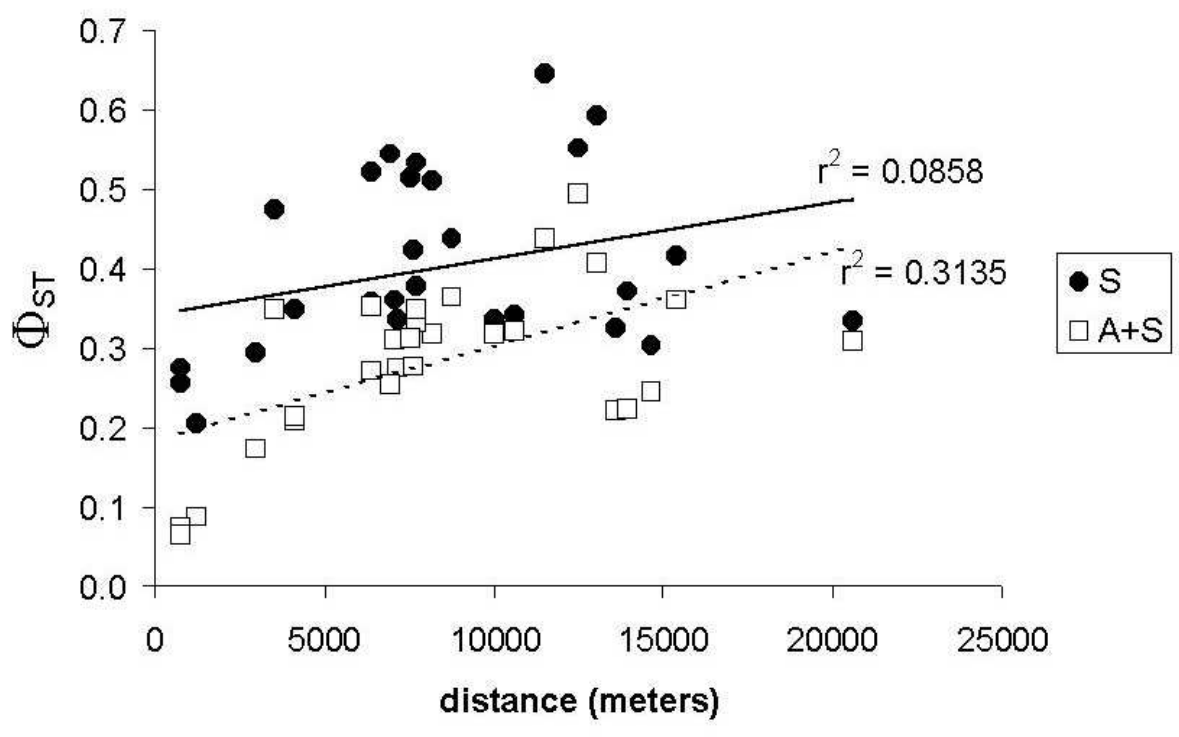

Figure 1 - Correlation between genetic differentiation $\left(\Phi_{S T}\right)$ and physical distance for all fragments using seedlings and adults plus seedlings. Solid line is related to seedlings data and dashed to adults plus seedlings. 
Measures of Jaccard similarity coefficient, used to make the dendrograms (Fig. 3a and b), are shown in the Tables 3 and 4 . When adults and seedlings of each fragment were analyzed together (Figura $3 a$ ), it was possible to observe the formation of two clusters, with the isolation of PEMG of the other analyzed fragments. When considering the 10 adult individuals as a group, apart from seedlings (Fig. 3b), these were isolated of the other fragments, and PEMG formed a cluster with Fazenda Morungava.

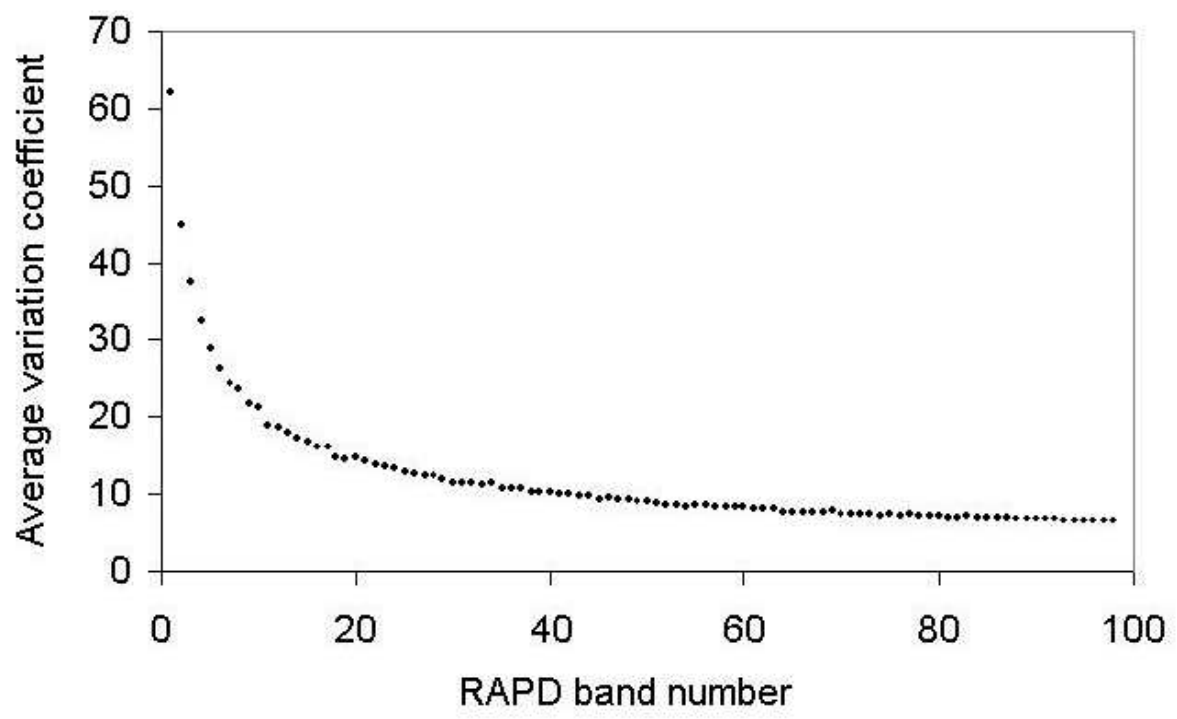

Figure 2 - Coefficients of variation for errors associated with estimated genetic distance calculated for different numbers of RAPD markers.

\section{DISCUSSION}

Although fragmentation may have strong genetic effects, these effects can vary in different situations due to biology of focal species, landscape and forest community structure. The overall genetic diversity level $\left(H_{T=0.2776)}\right.$ and the polymorphic loci percentage $(78.57 \%)$ of $A$. polyneuron, were close to some reports for other tropical species. Lerceteau et al., (1997) studied samples of an ex situ genetic bank of cocoa tree (Theobroma cacao L, Sterculiaceae), a small subcanopy tree, with animal-dispersed seeds and batpollinated flowers, and showed a total diversity $\left(H_{T}\right)$ of 0.340 for RFLP markers.

Whitkus et al. (1998), in an analysis with 57 markers of RAPD with samples of Theobroma cacao found a percentage of polymorphism of 77.2\%. Gillies et al. (1999) studied Mahogany populations (Swietenia macrophylla, Meliaceae), a species with wind-dispersed seeds like $A$. polyneuron, through RAPD markers and observed a Shannon index of diversity of 0.45 . In $A$. polyneuron a similar value of Shannon index was found $(I=0.446)$. However, none of these studies reported explicit fragmentation influence over populations.

These results could be auspicious for the conservation of A. polyneuron, if almost all of that genetic diversity was not confined to the pool of adults (established before fragmentation) in isolated fragments and only marginally maintained in the post-fragmentation cohorts in a single site, the "Mata dos Godoy" state park (PEMG), the only population with thousands of mature individuals.

As a result of long life of A. polyneuron, the recent fragmentation process of Northern Paraná has not affected, until now, the total genetic diversity in adult cohorts. However, it was clear that, in the seedlings pool, population size and gene flow reduction could be a concern for conservation.

While Hamrick (1990) revised several published isozyme analysis and suggested that outbreeding tropical trees usually keep a higher level of genetic diversity within than between populations, 
Chalmers et al. (1992) found most of genetic diversity occurring between populations of two Gliricidia species with RAPD markers. However, Chalmers et al. (1992) pointed out that isozyme analysis could not be directly compared to RAPD data. Our results agreed with Hamrick (1990), but the adults in this study were part of a single, large interconnected population before fragmentation. Thus, only the genetic profile of seedlings could be considered as result of discrete populations.
Physical distance cannot be used to predict their genetic differentiation $\left(\Phi_{S T}\right)$, probably because an isolation threshold (where gene flow turn into zero) is reached very early, in the first kilometers. Some degree of correlation between $\Phi_{S T}$ and physical distance only can be observed when adults are incorporated in the analysis, as long as they are inhabitants of a continuous forest before, where there is a continuous decrease in gene flow.
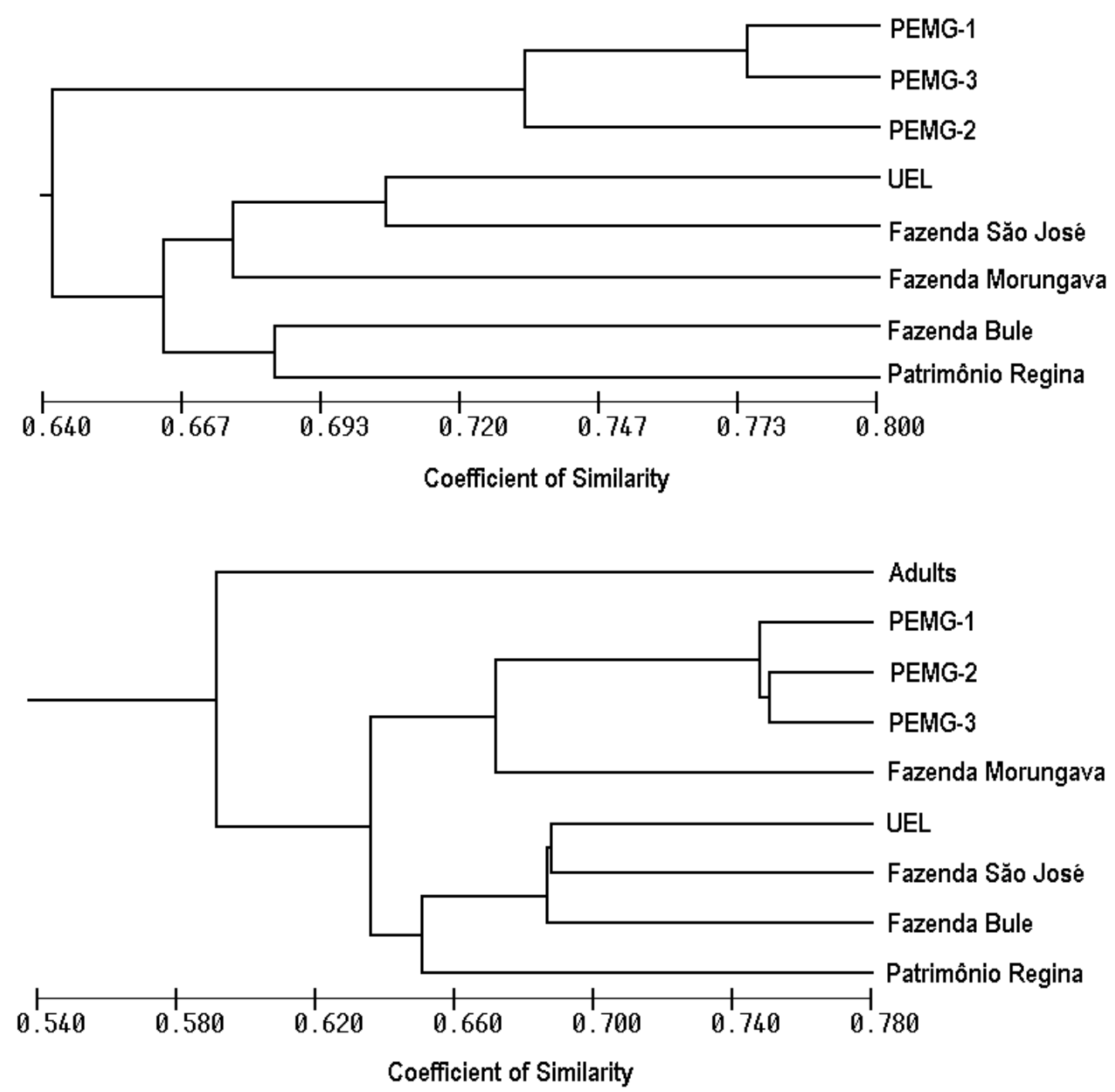

Figure 3 - Dendrograms based in Jaccard similarity coefficient for RAPD loci of Aspidosperma polyneuron populations of forest fragments in Northern Paraná region, Brazil. In "a", seedlings along adults by site (matrix correlation, $r=0.6969$; approximate Mantel t-test: $\mathrm{t}$ = 3.968); and in " $b$ " all adults joined in one group and seedlings by site (matrix correlation: $\mathrm{r}=0.8197 ; \mathrm{t}=3.696)$. 
Table 1 - Genetic diversity in adults and seedlings of Aspidosperma polyneuron (Apocynaceae) in forest fragments of Londrina region, Paraná state, Brazil.

\begin{tabular}{|c|c|c|c|c|c|c|c|c|c|c|}
\hline \multirow[b]{2}{*}{ Forest fragment } & \multicolumn{2}{|c|}{$N$} & \multicolumn{2}{|c|}{$\boldsymbol{H}$} & \multicolumn{2}{|c|}{$I$} & \multicolumn{2}{|c|}{$\boldsymbol{P}$} & \multicolumn{2}{|c|}{$\% P$} \\
\hline & $S^{1}$ & $\mathbf{A}+\mathbf{S}^{2}$ & $\mathbf{S}$ & $\mathbf{A}+\mathbf{S}$ & $\mathbf{S}$ & $\mathbf{A}+\mathbf{S}$ & $\mathbf{S}$ & $\mathbf{A + S}$ & $\mathbf{S}$ & $\mathbf{A}+\mathbf{S}$ \\
\hline PEMG-1 & 6 & 7 & 0.188 & 0.253 & 0.237 & 0.342 & 40 & 59 & 41.84 & 60.20 \\
\hline PEMG-2 & 6 & 7 & 0.294 & 0.315 & 0.383 & 0.429 & 66 & 74 & 67.35 & 75.51 \\
\hline PEMG-3 & 5 & 7 & 0.159 & 0.288 & 0.176 & 0.390 & 29 & 66 & 29.59 & 67.34 \\
\hline Campus UEL & 7 & 8 & 0.189 & 0.180 & 0.233 & 0.245 & 39 & 42 & 39.80 & 42.86 \\
\hline Fazenda Morungava & 5 & 7 & 0.087 & 0.162 & 0.099 & 0.218 & 17 & 37 & 17.35 & 37.75 \\
\hline Fazenda São José & 6 & 7 & 0.129 & 0.125 & 0.167 & 0.177 & 30 & 33 & 30.61 & 33.67 \\
\hline Patrimônio Regina & 7 & 8 & 0.232 & 0.208 & 0.295 & 0.293 & 56 & 57 & 57.14 & 58.16 \\
\hline Fazenda Bule & 6 & 7 & 0.106 & 0.141 & 0.143 & 0.198 & 28 & 38 & 28.57 & 38.78 \\
\hline Total PEMG & 17 & 21 & 0.281 & 0.312 & 0.386 & 0.448 & 74 & 83 & 64.29 & 74.49 \\
\hline Only Adults ${ }^{3}$ & 10 & - & 0.287 & - & 0.410 & - & 82 & - & 83.67 & - \\
\hline Total & & 58 & & & & & & 2 & & \\
\hline
\end{tabular}

$N$ : number of plants studied; $H$ : Nei (1978) genetic diversity coefficient; $I$ : f Shannon genetic diversity index; $P:$ number of polymorphic loci; \%P: percent of polymorphic loci $(95 \%) ;{ }^{1}$ : Genetic diversity parameters of the seedlings; ${ }^{2}$ : Genetic diversity parameters of the seedlings and adults; ${ }^{3}:$ Genetic diversity parameter of all adults.

Table 2 - Fixation index $\left(\Phi_{S T}\right)$ and gene flow $(\mathrm{Nm})$ of A. polyneuron in forest fragments of Londrina region, Paraná state, Brazil.

\begin{tabular}{|c|c|c|c|c|c|c|}
\hline & \multicolumn{3}{|c|}{ Adults + Seedlings } & \multicolumn{3}{|c|}{ Adults $x$ Seedlings } \\
\hline & $N$ & $\Phi_{S T}$ & $N m$ & $N$ & $\Phi_{S T}$ & $\mathrm{Nm}$ \\
\hline PEMG1 x PEMG2 & 14 & $0.088 \pm 0.027^{\text {n.s. }}$ & 2.581 & 12 & $0.206 \pm 0.041^{*}$ & 0.964 \\
\hline PEMG1 x PEMG3 & 14 & $0.074 \pm 0.026^{\text {n.s. }}$ & 3.147 & 11 & $0.255 \pm 0.049^{*}$ & 0.731 \\
\hline PEMG1 x UEL & 15 & $0.222 \pm 0.042^{* *}$ & 0.875 & 13 & $0.325 \pm 0.060^{* *}$ & 0.519 \\
\hline PEMG1 x F. Morungava & 14 & $0.272 \pm 0.044^{* *}$ & 0.670 & 11 & $0.521 \pm 0.061^{* *}$ & 0.230 \\
\hline PEMG1 x F. São José & 14 & $0.275 \pm 0.033^{* *}$ & 0.658 & 12 & $0.337 \pm 0.046^{* *}$ & 0.493 \\
\hline PEMG1 x P. Regina & 14 & $0.173 \pm 0.042^{*}$ & 1.199 & 14 & $0.296 \pm 0.060^{* *}$ & 0.596 \\
\hline PEMG1 x F. Bule & 14 & $0.318 \pm 0.052^{* *}$ & 0.537 & 12 & $0.510 \pm 0.051^{* *}$ & 0.240 \\
\hline PEMG2 x PEMG3 & 14 & $0.063 \pm 0.034^{\text {n.s. }}$ & 3.693 & 11 & $0.276 \pm 0.043^{*}$ & 0.657 \\
\hline PEMG2 x UEL & 15 & $0.244 \pm 0.041^{* *}$ & 0.773 & 13 & $0.304 \pm 0.047^{* *}$ & 0.573 \\
\hline PEMG2 x F. Morungava & 14 & $0.276 \pm 0.039^{* *}$ & 0.654 & 11 & $0.424 \pm 0.047^{* *}$ & 0.340 \\
\hline PEMG2 x F. São José & 14 & $0.352 \pm 0.039^{* *}$ & 0.460 & 12 & $0.359 \pm 0.045^{* *}$ & 0.447 \\
\hline PEMG2 x P. Regina & 14 & $0.210 \pm 0.030^{*}$ & 0.943 & 13 & $0.214 \pm 0.039^{*}$ & 0.918 \\
\hline PEMG2 x F. Bule & 14 & $0.332 \pm 0.048^{* *}$ & 0.502 & 12 & $0.378 \pm 0.049^{* *}$ & 0.411 \\
\hline PEMG3 x UEL & 15 & $0.223 \pm 0.034^{* *}$ & 0.873 & 12 & $0.372 \pm 0.056^{* *}$ & 0.422 \\
\hline PEMG3 x F. Morungava & 14 & $0.253 \pm 0.041^{* *}$ & 0.739 & 10 & $0.545 \pm 0.068^{* *}$ & 0.209 \\
\hline PEMG3 x F. São José & 14 & $0.311 \pm 0.033^{* *}$ & 0.555 & 11 & $0.360 \pm 0.046^{* *}$ & 0.444 \\
\hline PEMG3 x P. Regina & 14 & $0.214 \pm 0.036^{*}$ & 0.918 & 12 & $0.349 \pm 0.047^{* *}$ & 0.467 \\
\hline PEMG3 x F. Bule & 14 & $0.313 \pm 0.054^{* *}$ & 0.548 & 11 & $0.515 \pm 0.064^{* *}$ & 0.236 \\
\hline UEL x F. Morungava & 15 & $0.348 \pm 0.045^{* *}$ & 0.469 & 12 & $0.534 \pm 0.052^{* *}$ & 0.218 \\
\hline UEL x F. São José & 15 & $0.309 \pm 0.058^{* *}$ & 0.560 & 13 & $0.333 \pm 0.568^{* *}$ & 0.501 \\
\hline UEL x P. Regina & 15 & $0.322 \pm 0.050^{* *}$ & 0.527 & 14 & $0.341 \pm 0.050^{* *}$ & 0.484 \\
\hline UEL x F. Bule & 15 & $0.360 \pm 0.060^{* *}$ & 0.444 & 13 & $0.416 \pm 0.054^{* *}$ & 0.351 \\
\hline F. Morungava x F. São José & 14 & $0.406 \pm 0.050^{* *}$ & 0.365 & 11 & $0.593 \pm 0.056^{* *}$ & 0.172 \\
\hline F. Morungava x P. Regina & 14 & $0.349 \pm 0.053^{* *}$ & 0.466 & 12 & $0.474 \pm 0.055^{* *}$ & 0.277 \\
\hline F. Morungava x F. Bule & 14 & $0.437 \pm 0.064^{* *}$ & 0.322 & 11 & $0.647 \pm 0.053^{* *}$ & 0.136 \\
\hline
\end{tabular}


Cont. Table 2

\begin{tabular}{lcccccc}
\hline F. São José x P. Regina & 14 & $0.318 \pm 0.054^{* *}$ & 0.537 & 13 & $0.335 \pm 0.052^{* * *}$ & 0.496 \\
F. São José x F. Bule & 14 & $0.495 \pm 0.059^{* *}$ & 0.255 & 12 & $0.551 \pm 0.060^{* *}$ & 0.203 \\
P. Regina x F. Bule & 14 & $0.364 \pm 0.063^{* *}$ & 0.437 & 13 & $0.437 \pm 0.057^{* *}$ & 0.322 \\
PEMG1 x Adults & - & - & - & 16 & $0.296 \pm 0.039^{* *}$ & 0.594 \\
PEMG2 x Adults & - & - & - & 16 & $0.148 \pm 0.032^{*}$ & 1.440 \\
PEMG3 x Adults & - & - & - & 15 & $0.378 \pm 0.037^{* *}$ & 0.412 \\
UEL x Adults & - & - & - & 17 & $0.276 \pm 0.035^{* *}$ & 0.656 \\
F. Morungava x Adults & - & - & - & 15 & $0.432 \pm 0.040^{* *}$ & 0.329 \\
P. Regina x Adults & - & - & - & 17 & $0.215 \pm 0.041^{* *}$ & 0.915 \\
F. São José x Adults & - & - & - & 16 & $0.375 \pm 0.040^{* *}$ & 0.417 \\
F. Bule x Adults & - & - & - & 16 & $0.408 \pm 0.042^{* *}$ & 0.363 \\
\hline
\end{tabular}

$* \mathrm{p}<0.05, * * \mathrm{p}<0.01$

Table 3 - Jaccard similarity coefficient in adults and seedlings of A. polyneuron in forest fragments of Londrina region, Paraná state, Brazil.

\begin{tabular}{lc|c|c|c|c|c|c}
\hline & PEMG-1 & PEMG-2 & PEMG-3 & UEL & $\begin{array}{c}\text { Fazenda } \\
\text { Morungava }\end{array}$ & $\begin{array}{c}\text { Fazenda } \\
\text { São José }\end{array}$ & $\begin{array}{c}\text { Patrimônio } \\
\text { Regina }\end{array}$ \\
\hline PEMG-2 & 0.7156 & & & & & & \\
PEMG-3 & 0.7767 & 0.7512 & & & & & \\
UEL & 0.6383 & 0.5469 & 0.6245 & & & & \\
Fazenda Morungava & 0.6858 & 0.6053 & 0.6986 & 0.6505 & & & \\
Fazenda São José & 0.6943 & 0.6043 & 0.6659 & 0.7088 & 0.7042 & & \\
Patrimônio Regina & 0.6855 & 0.5996 & 0.6288 & 0.6273 & 0.6482 & 0.6961 & \\
Fazenda Bule & 0.6920 & 0.6214 & 0.6667 & 0.6810 & 0.6645 & 0.6769 & 0.6864 \\
\hline
\end{tabular}

Table 4 - Jaccard similarity coefficient of adults x seedlings of A. polyneuron in forest fragments of Londrina region, Paraná state, Brazil.

\begin{tabular}{lc|c|c|c|c|c|c|c}
\hline & Adults & PEMG-1 & PEMG-2 & PEMG-3 & UEL & $\begin{array}{c}\text { Fazenda } \\
\text { Morungava }\end{array}$ & $\begin{array}{c}\text { Fazenda } \\
\text { São José }\end{array}$ & $\begin{array}{c}\text { Patrimônio } \\
\text { Regina }\end{array}$ \\
\hline PEMG1 & 0.6219 & & & & & & & \\
PEMG2 & 0.5954 & 0.7506 & & & & & & \\
PEMG3 & 0.5684 & 0.7459 & 0.7549 & & & & & \\
UEL & 0.6204 & 0.6486 & 0.5884 & 0.6119 & & & & \\
Fazenda Morungava & 0.5431 & 0.6472 & 0.6485 & 0.7221 & 0.5990 & & & \\
Fazenda São José & 0.6041 & 0.7118 & 0.6469 & 0.6632 & 0.6919 & 0.5990 & & \\
Patrimônio Regina & 0.6232 & 0.6805 & 0.6335 & 0.6317 & 0.6195 & 0.6146 & 0.6798 & \\
Fazenda Bule & 0.5653 & 0.6884 & 0.6524 & 0.6604 & 0.6898 & 0.6037 & 0.6878 & 0.6609 \\
\hline
\end{tabular}

The results of $\Phi_{S T}$ analysis indicated a high degree of genetic structure in the studied forest fragments (Table 2). However, gene flow estimation $(\mathrm{Nm})$ among PEMG samples and Patrimônio Regina contrasted with Jaccard results, where only among PEMG samples a higher degree of similarity could be observed. Though A. polyneuron trees are longlived, catastrophic events, such as tropical storms, have been causing more damage in small than in large forest fragments, due to edge effects, which increase broken and fallen trees frequency (Laurance, 1997). The loss of mature adults (prefragmentation) in small fragments may not be counterbalanced by recruitment of seedlings (postfragmentation), as long as in most of the sites the seedlings are not genetically diverse, as can be clearly observed in Fazenda Morungava and Fazenda Bule sites. 
Demographic data indicated that fecundity of $A$. polyneuron trees did not seem to be a problem for the maintenance of viable populations. Average seedling density ( 0.1 to $1 \mathrm{~m}$ in height) was $22,000 . \mathrm{ha}^{-1}$, which dropped to less than $1000 \cdot \mathrm{ha}^{-1}$ for saplings $(1 \mathrm{~m}$ in height to $5 \mathrm{~cm} \mathrm{DBH}$; Pires 1995) in PEMG, where average adult density was 98. ha ${ }^{-1}$ (Soares-Silva and Barroso, 1992). However, each loss of an adult in small fragments with few mature trees could reduce seed rain and consequently weak regeneration, besides of genetic losses. In spite we made no seedling inventory, we observed that in some of our study sites, seedling density was far less than in PEMG.

As could be seen in dendrogram (Fig. 3b), genetic distance data of the adult's pool against seedlings from different sites showed that there was no site where seedlings grouped with adults. Thus, the allelic frequencies in seedlings already showed changes, when compared to the pre-fragmentation scenario, which could be accredited to reduction of both number of mature adults and gene flow. According to Moritz (1994), the divergence in allele frequencies among populations, regardless of distinctiveness of alleles themselves could turn those populations in independent "management units". As pointed out by Paetkau (1999) in early phases of an isolation process, local populations could be genetically homogenous, but should be managed independently. The fragmentation process in Northern Paraná began 60 years ago and all studied fragments were in recent isolation, but exhibited some degree of genetic divergence. All fragments in this study could be considered as several operational units. The goal of identifying management units is to help select spatially structured reserves of most of the genetic diversity of a species (Diniz-Filho and Telles, 2002). However, there is a need to ensure the viability of conservation inside each operational unit and to keep an adequate gene flow, besides of creating preserves of most genetic diversity. Restricted gene flow could strongly impair survival of populations sizing fewer than 100 individuals (Couvet, 2002), and most of A. polyneuron populations of forest fragments in the study area were under this size.

Genetic diversity results indicated that the contribution of seedlings to overall polymorphism, with exception of PEMG, was decreasing, and allele fixation could be occurring in the process of recruitment. A few migrants per generation could contribute to revert this situation (Couvet, 2002), but this could only be achieved in a short time by transplanting seedlings, because of the late reproduction of the species. Corridors allowing pollinators transit and containing sites for establishment of $A$. polyneuron individuals can be efficient only in the long time.

Genetic data presented here was useful in revealing patterns of effects of habitat fragmentation in the studied species and showing the importance of local populations in the conservation of A. polyneuron. Although PEMG is unquestionably an important part of a regional strategy for conservation, it cannot be sufficient alone. Thus, the establishment of a system of reserves, based on remaining forest fragments, is imperative. Such a system should provide (1) buffer zones for protection of small forest fragments from edge effects, (2) mature trees active protection (e.g. controlling vines), (3) active transfer of seeds or seedlings among management units (i.e. forest fragments) and (4) plantation of seedlings with reasonable polymorphism in restoration areas near and directly into remnants. Forest fragmentation, due to clearing and selective logging, drive Atlantic forests of Northern Paraná region to a situation that, even if no more forest is cleared, the remaining patches can no longer sustain all biodiversity components in a short time scale, and the only way to halt this tendency is to manage the remnants and increase forest area by reforesting.

\section{ACKNOWLEDGEMENTS}

This work was supported by Fundação O Boticário de Proteção à Natureza (process number 047520002) and CPG-UEL. Authors thanks Dr. Waldemar de Paula Carvalho for help with statistics.

\section{RESUMO}

O método de RAPD foi usado para acessar a variabilidade genética em Aspisdosperma polyneuron, uma árvore tropical de vida longa e idade reprodutiva tardia, e muito importante na Floresta Atlântica. Amostras foram coletadas em seis fragmentos florestais na região da cidade de Londrina (Sul do Brasil), uma paisagem fragmentada na década de 30 . O perfil de RAPD 
foi analisado em adultos (pré-fragmentação, >300 anos) e plântulas (pós-fragmentação, $<<50$ anos). Os resultados mostram uma queda no polimorfismo genético em gerações pósfragmentação nos pequenos fragmentos e alta diversidade genética dentro das populações. A distribuição da diversidade genética sugere o estabelecimento dos fragmentos como reservas protegidas, e a transferência de plântulas entre os fragmentos para a conservação de A. polyneuron.

\section{REFERENCES}

Caraffa, V. B.; Giannettini, J.; Gambotti, C. and Maury, J. (2002), Genetic relationships between cultivated and wild olives of Corsica and Sardinia using RAPD markers. Euphytica, 123, 263-271.

Chalmers, K. J.; Waugh, R.; Sprent, J. I.; Simons, A. J. and Powell, W. (1992), Detection of genetic variation between and within populations of Gliricidia sepium and G. maculata using RAPD markers. Heredity, 69, 465-472.

Couvet, D. (2002), Deleterious effects of restricted gene flow in fragmented populations. Conservation Biology, 16, 369-376.

Diniz-Filho, J. A. F. and Telles, M. P. C. (2002), Spatial autocorrelation analysis and the identification of operational units for conservation in continuous populations. Conservation Biology, 16, 924-935.

Eizirik, E. (1996), Ecologia molecular, genética da conservação e o conceito de unidades evolutivamente significativas. Brazilian Journal of Genetics, 19, 23-29.

Ferreira, M. E. and Grattapaglia, D. (1995), Introdução ao uso de marcadores RAPD e RFLP em análise genética. 2. ed. Brasília : Embrapa-Cenargen. 220 pp.

Gillies, A. C. M.; Navarro, C.; Lowe, A. J.; Newton, A. C.; Hernandez, M.; Wilson, J. and Cornelius, J. P. (1999), Genetic diversity in Mesoamerican populations of mahogany (Swietenia macrophylla), assessed using RAPDs. Heredity, 83, 722-732.

Hamrick, J. L. (1990), Isosyme analysis of genetic structure in plant population. In: Soltis, D. E. and Soltis, P. S. (Eds.). Isozymes in plant biology. Portland : Dioscorides Press. pp. 87-105.

Kapos, V. (1989), Effects of isolation on water status of forest patches in the Brazilian Amazon. Journal of Tropical Ecology, 5, 173-185.

Kapos, V. (1989), Effects of isolation on water status of forest patches in the Brazilian Amazon. Journal of Tropical Ecology, 5, 173-185.
Laurance, W. F. (1997), Hyper-disturbed parks: edge effects and the ecology of isolated rainforest reserves in tropical Australia. In: Laurance, W. F, and Bierregaard Jr., R. O. (Eds.). Tropical Forest Remnants, Chicago, The University of Chicago Press. pp.71-85.

Lerceteau, E., Robert, T., Petiard, V. and Crouzillat, D. (1997), Evaluation of the extent of genetic variability among Theobroma cacao accessions using RAPD and RFLP markers. Theoretical and Applied Genetics, 95, 10-19.

Lynch, M. and Milligan, B. G. (1994), Analysis of population genetic structure with RAPD markers. Molecular Ecology, 3, 91-99.

Malcolm, J. R. (1994), Edge effects in central Amazonian forest fragments. Ecology, 75, 2438-2445.

Mantel, N. (1967), The detection of disease clustering and a generalized regression approach. Cancer Research, 27, 209-220.

Miller, M. P. (1997), Tools for population genetic analysis (TFPGA) 1.3: A Windows program for the analysis of allozyme and molecular population genetic data. Department of Biological Sciences, Northern Arizona University, Flagstaff, Arizona. Disp. in: http://www.public.asu.edu/ mmille8/tfpga.htm.

Accessed: 20 dez. 2000.

Moritz, C. (1994), Defining "Evolutionary Significant Units" for conservation. Trends Ecology and evolution, 9, 373-375.

Murcia, C. (1996), Forest fragmentation and the pollination of neotropical plants. In: Schelhas, J. and R. Greenberg (Eds.). Forest Patches in Tropical Landscapes. Washington, D.C. : Iland Press. pp. 149-186.

Paetkau, D. (1999), Using genetic to identify intraspecific conservation units: a critique of current proposals. Conservation Biology, 13, 1507-1509.

Pires, L. A. (1995), Estudo da regeneração natural no Parque Estadual "Mata dos Godoy". Londrina, Monografia (Bacharelado), Universidade Estadual de Londrina, Londrina. pp.1-25.

Sales, E.; Nebauer, S. G.; Mus, M. and Segura, J. (2001), Population genetic study in the Balearic endemic plant species Digitalis minor (Scrophulariaceae) using RAPD markers. American Journal of Botany, 88, 1750-1759.

Simberloff, D. (1998), Flagships, umbrellas and keystones: Is single-species management passé in the landscape era? Biological Conservation, 83, 247-257.

Soares-Silva, L. H. and Barroso, G. M. (1992). Fitossociologia do estrato arbóreo da floresta na porção norte do "Parque Estadual Mata dos Godoy", Londrina-PR., Brasil. In: Congresso da Sociedade Botânica de São Paulo, 8. Anais... pp.101-112.

Trevisan, G. (1998). Biomassa e deposição de serapilheira no Parque Estadual "Mata dos Godoy". Monografia (Bacharelado), Universidade Estadual de Londrina, Londrina. pp. 1-56. 
Whitkus, R., Mota-Bravo, L., Gomez-Pompa, A. and De la Cruz, M. (1998). Genetic diversity and relationships of cacao (Theobroma cacao L.) in Southern Mexico. Theoretical and Applied Genetics, 96, 621-627.

Yeh, F.; Yang, R. and Boyle, T. (2000), Popgene version 1.32: A Microsoft Window-based freeware for population genetic analysis. Disp. in: http://www.ualberta.ca/ fyeh/info.htm. Accessed: 20 nov. 2002.

Yu, K. F.; Deynze, A. V. and Pauls, P. (1993), Random amplified polymorphic DNA (RAPD) analysis. In: Glick, B. R. and Thompson, J. E. (Eds.). Methods in Plant Molecular Biology and Biotechnology. CRC Press. pp. 1-360.

Received: March 31, 2003; Revised: December 12, 2003; Accepted: September 14, 2004. 